\title{
Formation of Drawing Activity in Mexican Pre-school Children
}

\author{
Yulia Solovieva, Luis Quintanar \\ Autonomous University of Puebla, Puebla, Mexico
}

\begin{abstract}
The pre-school age is the period of great importance for psychological development and preparation for school. The process of learning and achievements at school depends on the types of activities selected at pre-school level. Unfortunately, it is often to find out that introduction of writing and reading is among the most common activities in pre-school institutions all over the world. Instead of this, we propose drawing as suitable activity for children development. The original program for gradual formation of drawing by stages was elaborated. The program is based on the usage of the zone of proximate development and considers psychological structure of graphic activity. The program was applied in different pre-school institutions in Mexico. All children were tested before and after application of the program. Before the program, all children have shown absence of developed drawing activity. After program application all children showed qualitative positive achievements in graphic activity, such as spatial global and analytic orientation, essential features, and shapes of represented objects. We conclude that drawing is extremely useful activity for preparation for school learning, especially for writing process. Our program may be used in pre-school institutions in order to guarantee correspondent level or preparation for school learning.
\end{abstract}

Keywords: drawing activity, pre-school age, preparation for school, psychological development, original educational methods, spatial orientation, prevention of learning disabilities

\section{Introduction}

It is well known that pre-school age is the period of great importance for psychological development of children and preparation for school (Elkonin, 1995; Salmina, 2010). According to psychological and neuropsychological research, the pre-school age is the age of significant changes and transformations in children's activity and personality (Vigotsky, 1996; Obukhova, 2006; Elkonin, 2009; Salmina \& Filimonova, 2001). The process of learning and achievements at school depends on the types of activities selected for pre-school level in private and public educational institutions. Unfortunately, it is often to find out that introduction of writing and reading is among the most common activities in pre-school institutions all over the world. The luck of educational innovations and proposals for original methods of teaching and prevention of learning disabilities is especially notable in Latin America.

Such situation is reflected in poor level of preparation for school, initial graphic abilities, and frequent learning disabilities at school age. For example, children commit a lot of mistakes in their writing. According to recent neuropsychological research, such difficulties are frequently related to poor level of acquisition of 
general spatial functions, such as global strategy of perception and orientation both with analytic strategy. Such data are found not only in Mexican children (Solovieva, Quintanar, \& Lázaro, 2002), but also described by neuropsychologists in other countries (Akhutina, 2002; Akhutina \& Pilayeva, 2003, 2012a, 2012b). In recent research related to neuropsychological assessment of children with learning disabilities at primary school, it has been detected that spatial dysfunctions appear at the second place after dysfunctions of regulation and control as the main reason of difficulties at school (Cisneros, 2010; Rojas, 2011). On the other hand, in children with attention deficit disorder severe, spatial difficulties are described as one of specific features within the clinic picture at pre-school (Quintanar, Solovieva, \& Bonilla, 2006; Solovieva, Machinskaya, Quintanar, Bonilla., \& Pelayo, 2009) and recently also at school age in children who assist the first three grades of primary school in Mexico (Paz, 2012).

Another poor aspect of functional element of brain systems is reception and production of images of objects or, in other words, fine visual perception. Different studies have detected impropriate development of visual images of concrete objects at the end of pre-school age (Rocha, Quintanar, \& Solovieva, 2005; Glozman, 2009; Solovieva \& Quintanar, 2008; Akhutina, Kamardina, \& Pilayeva, 2012). In such cases, we can claim that pre-school and school children frequently show low level of development of spatial functions which produce negative effects in their learning process. According to neuropsychological research (Akhutina \& Zolotariova, 2007; Akhutina \& Inshakova, 2008; Akhutina \& Pilayeva, 2012a), the most common difficulties in writing at primary school related to poor spatial and visual functions are:

(1) Wrong separations of words and sentences;

(2) Inversions of letters and element of letters;

(3) Disproportions of letters and elements of letters;

(4) Losing of the base line in writing;

(5) Confusion with election of shapes and size of letters and elements of letters;

(6) Wrong or confusing inclination;

(7) General difficulties with spatial organization of graphic elements on paper.

All presented data permit to claim the necessity of elaboration of specific programs not only for correction, but also for prevention of learning disabilities. Current psychological studies, within historic and cultural conception of psychological development (Vigotsky, 1995), make an effort to elaborate interesting proposals for methods of work in preschool institutions. Among such proposals, we can mention studies related to development of functions of programming and control (Akhutina \& Pilayeva, 2012b) and preparation for mathematic reasoning (Pilayeva \& Akhutina, 2009). Other examples are recent publications related to introduction of numeric, logic, and symbolic components of mathematic abilities at the end of pre-school age (Salmina, 2009; Salmina \& Filimonova, 2010). All mentioned works and methods try to show that it is possible to guarantee high level of preparation for school learning without insisting in mechanic reproductions and copy of letters and numbers at pre-school age. Following these efforts, in this article, we propose specific methodology for step-by-step introduction and formation of drawing activity as a necessity of psychological age and of preparation for school learning in proximate future.

The objective of the present study is to show the efficiency of our program for gradual formation of drawing in Mexican pre-school children. 


\section{Method}

\section{Sample}

The subjects of the study are 60 Mexican pre-school children divided in two groups: control group (30 children) and experimental group (30 children). All children belonged to suburban area of the state of Tlaxcala (Central Mexico) and assisted to pre-school official level for the first time. The children belonged to suburban zone with poor medical, cultural, and social attention. The average level of education of parents of children was primary school. The fathers were dominantly small merchants; the mothers were housekeepers. The age of children was between five to six years old $(X=5.4)$. All children were regular pupils of official kinder garden. The children assisted pre-school education during one year: The last year before entering official primary school. The children presented no kinds of problems in their psychological development.

\section{Initial and Final Assessment of Drawing Activity}

The study consisted in three phases: initial assessment of the level of drawing activity, application of the method for formation of graphic activity during six months, and final assessment of achievements of drawing activity. All children were tested before and after application of the program. Specific tasks were selected from Brief Neuropsychological Assessment (Solovieva \& Quintanar, 2009) and other special tasks for drawing were elaborated for this study. Among the tasks were included: copy of objects with elements of spatial orientation, free drawing, and production of drawings by categorical instructions (see Table 1).

Table 1

Description of the Tasks for Assessment of the Level of Acquisition of Drawing Activity

\begin{tabular}{|l|l|}
\hline Task & Instruction \\
\hline Spontaneous drawing (three minutes) & $\begin{array}{l}\text { Draw as much different objects (pictures) as you can. I tell you } \\
\text { when you should stop }\end{array}$ \\
\hline $\begin{array}{l}\text { Drawing of six animals in the sheet of paper divided in } \\
\text { six squares }\end{array}$ & $\begin{array}{l}\text { In each square draw one animal. You have to draw different } \\
\text { animals }\end{array}$ \\
\hline $\begin{array}{l}\text { Copy of four objects: cactus, glass, bottle and wolf } \\
\text { (see example 1 in Figure 1) }\end{array}$ & Copy these objects as they are \\
\hline Free drawing of three objects & Draw three things, which you like more \\
\hline Drawing of a square table with four legs & Draw a square table with four legs \\
\hline Copy of a house (see example 2 in Figure 2) & Draw this house \\
\hline
\end{tabular}
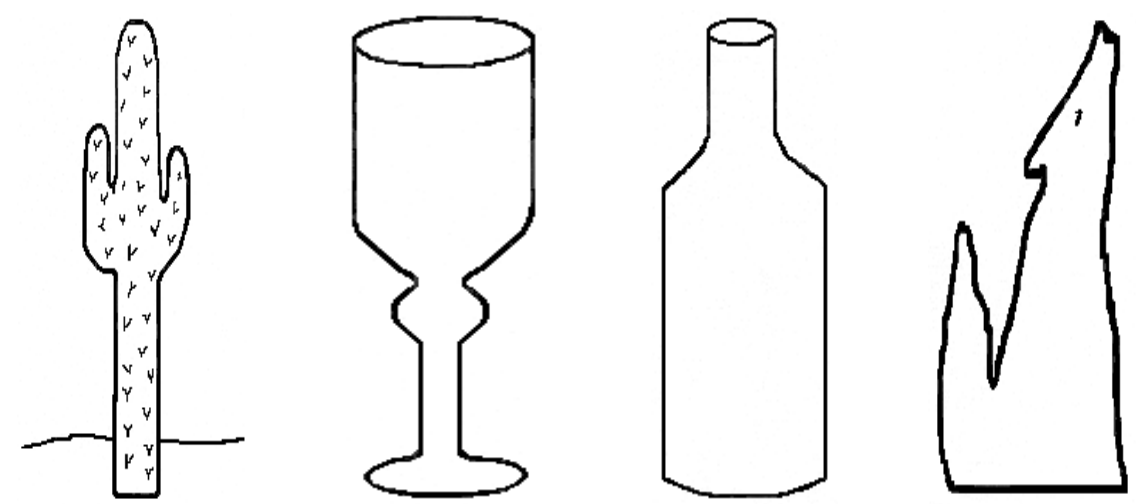

Figure 1. Example 1: Models of four objects (copy). 


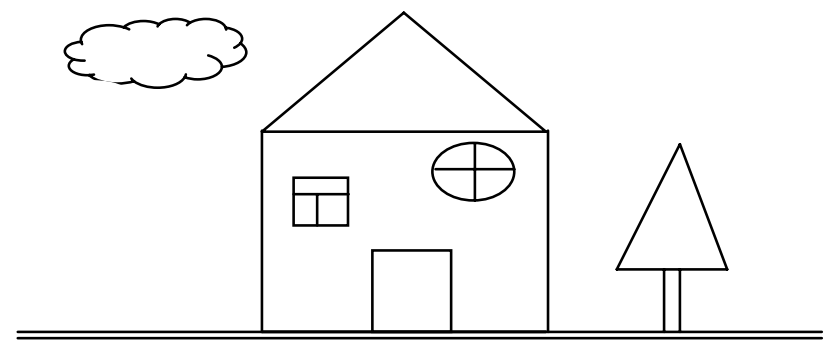

Figure 2. Example 2: Model of a house (copy).

\section{Program}

The original program (Solovieva \& Quintanar, in press) for gradual formation of drawing by stages was created. The program is based on the following theoretical and methodological concepts of historic and cultural psychology and activity theory:

(1) Historic and cultural paradigm of psychological development (Vigotsky, 1995; Leontiev, 1983) which means creation and elaboration of specific types of activities in order to guarantee psychological development of children;

(2) The theory of step-by-step formation of mental actions (Galperin, 1976) which means to start from external material and materialized levels of actions;

(3) Orientation base of action during the introduction of new actions (Talizina, 2009) which means elaboration of specific kinds of orientation for gradual development of drawing;

(4) The zone of proximate development which means the possibility of constant collaboration between adult and children for achievement of common purpose (Vigotsky, 1996).

The program was created according to proposals of activity theory considering psychological structure of drawing: necessity, motive (object of activity), objective, orientation, means, and operations:

(1) Necessity: social necessity of communication;

(2) Motive: representation of objects, cognitive broad motivation, and formation of esthetic motivation;

(3) Objective: gradual reflection of the objective for representation of objects and features, real and imaginary situations;

(4) Object: visual perceptive image of objects;

(5) Orientation: introduced and shared by constant participation of pedagogue, analysis of features of the objects, and external presentation of shapes of the objects (squares, circles, ovals, triangles, rectangles, stars, drops, and so on);

(6) Operations and means: usage of pencils, colors, paper, shapes and details of real objects, and different graphic means.

Within the drawing activity, it is possible to distinguish specific actions. Such actions have to appear in the conscience of the children so that they could have a reflection of the object and goal of their action. After having being consciousness, such actions can pass to the plan of automatic internal operations. During practical work with the children, it was necessary to introduce all these actions one by one, starting from the external level and then passing them to internal perceptive level. The pedagogue had to reflect and organize all these actions together with the children. Only in such a case, the zone of proximate development can be achieved successfully. The actions, which were taken into account in our study as elements of drawing activity, are: 
(1) Initial election of the object which will be drawn; the object can be real or represented as perceptive image or model for drawing;

(2) Organization of the space on paper for representation of the general shape and essential elements of the object;

(3) Determination of the general predominate shape of the object;

(4) Election and disposition of the details of the objects;

(5) Representation of the shape of object with the help of external shape;

(6) Representation of specific details of the object;

(7) Verification and control of the whole execution, comparison with the model, detection of errors, and correction of errors.

The program was applied in experimental group for seven months daily during one hour in children's kindergarten. The work was fulfilled by a pedagogue who was a student of Master Program in Neuropsychology of Faculty of Psychology of Autonomous University of Puebla. The teacher of was only passive observer of proposed activities. The control group had no graphic activity as it usually happens according to official program applied in pre-school institutions.

The experimental program included four steps:

(1) Previous stage (preparation of drawing);

(2) Drawing of independent objects according to the shape and external model;

(3) Drawing of objects which enriched features according to internal model;

(4) Drawing of situations ("landscape" and "nature mort") according to external and internal model.

This study reflects only the results of application of the first two stages of the program, which were achieved during the period of seven months. All activities were realized in group of children with constant participation and orientation of pedagogue (see Table 2).

Table 2

Contents of Activities of the Program

\begin{tabular}{|l|l|}
\hline First stage: Preparation of drawing; external actions & Content and examples of activities \\
\hline Denomination of objects & $\begin{array}{l}\text { Different kinds of toys, objects, animals, instruments, which are new and } \\
\text { interesting, can be used (see example 3 in Figure 3) }\end{array}$ \\
\hline Identification of all kinds of feature in the objects & $\begin{array}{l}\text { Color, shape, spatial orientation, transparent, solid, liquid, big, fat, tall, } \\
\text { thin, all kinds of synonyms and antonyms can be used }\end{array}$ \\
\hline Comparison of all kinds of feature in the objects & Comparison of all kind of features in real objects \\
\hline Identification of the shape of objects & $\begin{array}{l}\text { Usage of external shapes, made of paper or plastic 5 } \times 5 \text { cm (see example } \\
4 \text { in Figure 4) }\end{array}$ \\
\hline $\begin{array}{l}\text { Comparison and classification of objects according to } \\
\text { the shape }\end{array}$ & Constant usage of external shapes \\
\hline $\begin{array}{l}\text { Identification of spatial characteristics of objects and } \\
\text { details }\end{array}$ & $\begin{array}{l}\text { High-low, close-opened, up-down, close-far, left-right, inside-outside, } \\
\text { etc. }\end{array}$ \\
\hline Comparison of perceptive representations of objects & $\begin{array}{l}\text { Pictures, photos, drawing, illustrations, postcards, and so on (see example } \\
5 \text { in Figure 5) }\end{array}$ \\
\hline Symbolic representation of gestures & $\begin{array}{l}\text { How to clean the table, how to paint the wall, how to close the door, how } \\
\text { to open the window, etc. }\end{array}$ \\
\hline Symbolic representation of lines on the paper & $\begin{array}{l}\text { The rain, the rainbow, the sun shining, snow, water, sea, stars, sand, grass, } \\
\text { and so on }\end{array}$ \\
\hline Representation of shapes & On the blackboard, on the sand, in space, on the shoulder of a friend, etc. \\
\hline
\end{tabular}




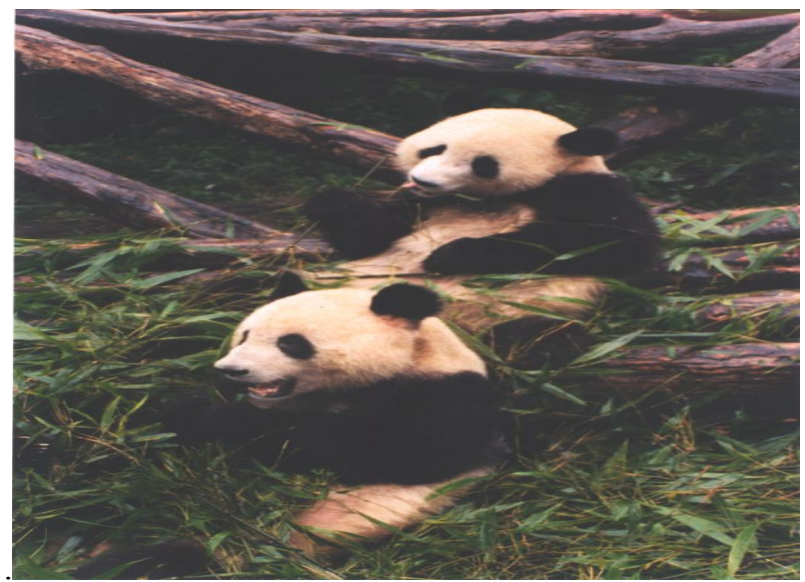

Figure 3. Example 3: An object used on this stage.

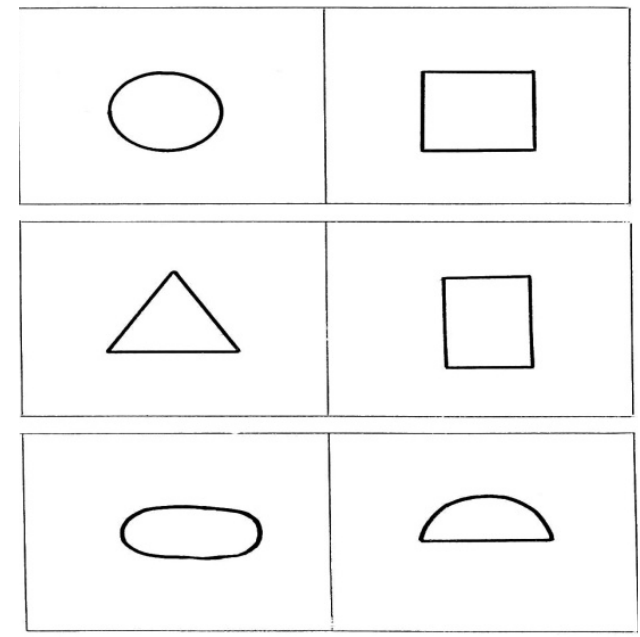

Figure 4. Example 4: External shapes.

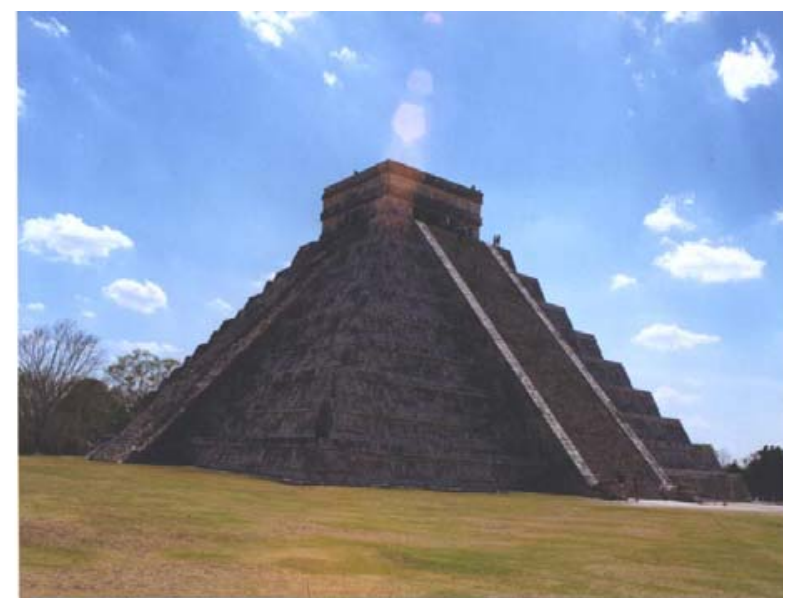

Figure 5. Example 5: Photo used on perceptual level during formation of drawing.

The second stage includes the work on gradual introduction of drawing of object itself. This activity was always based on the usage of models of objects (toys, instruments, fruits, furniture, etc.). External shapes were constantly used during this stage. 


\section{Results}

After the application of experimental program for formation of drawing activity, the children from experimental group showed qualitative positive achievements in graphic representations of objects, spatial orientation, number of drawings elaborated in three minutes and of essential features of represented objects (see examples 6-11 in Figures 6-11).
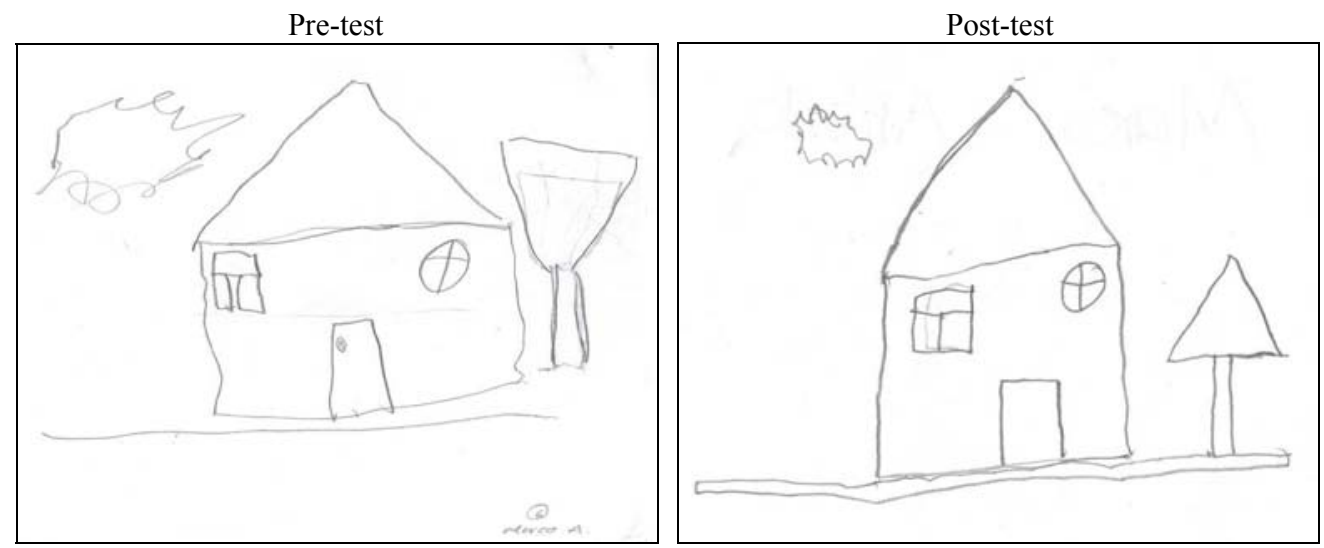

Figure 6. Example 6: Copy of the house, before and after application of the program.

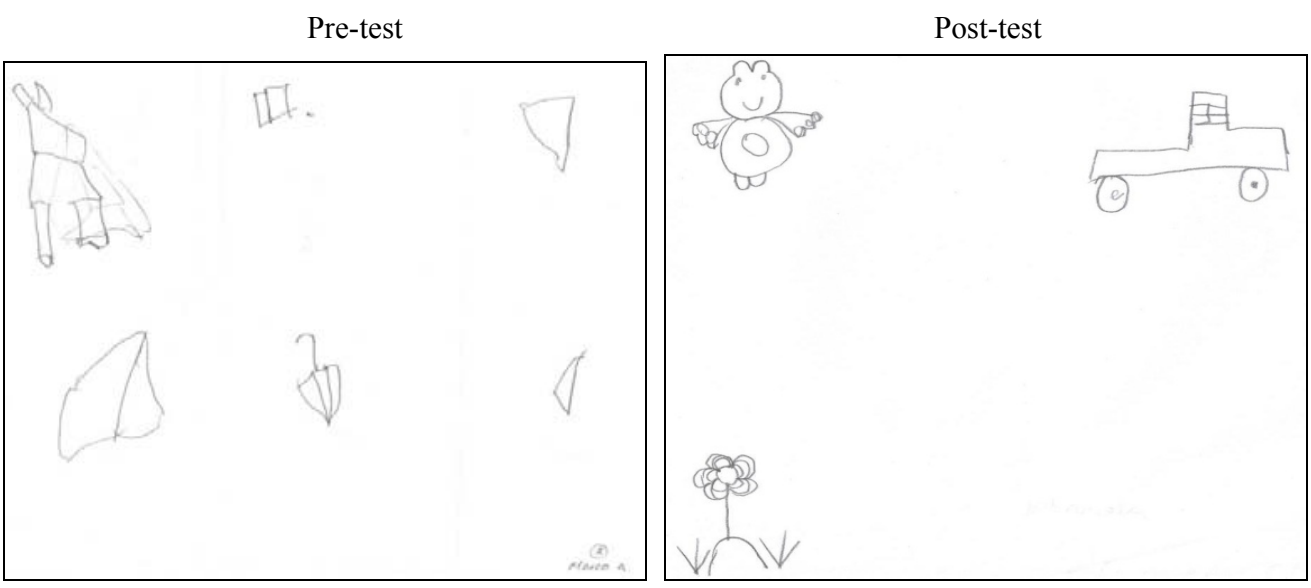

Figure 7. Example 7: Free drawing, before and after application of the program ("Draw three things you like more").
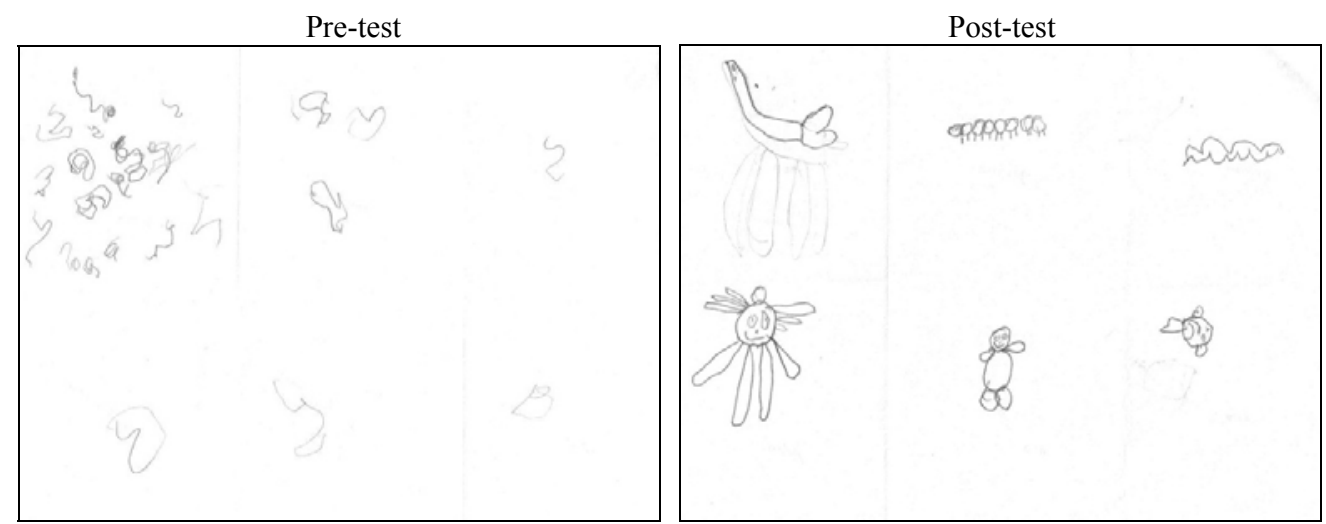

Figure 8. Example 8: Free drawing, before and after application of the program ("Draw six animals"). 

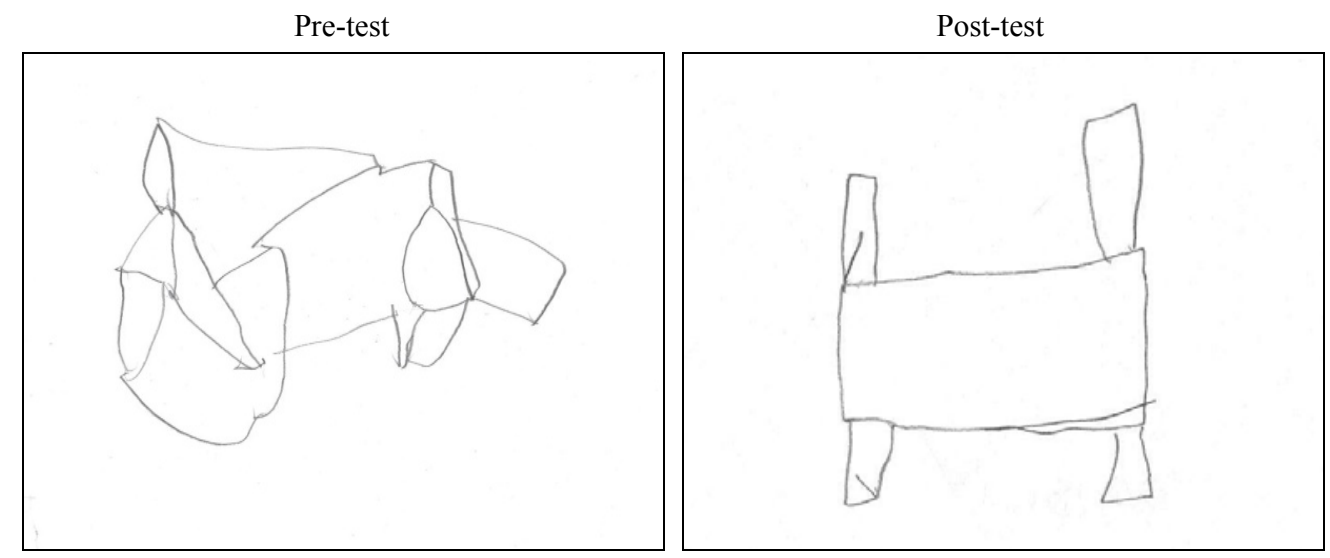

Figure 9. Example 9: Free drawing, before and after application of the program ("Draw a table with four legs").
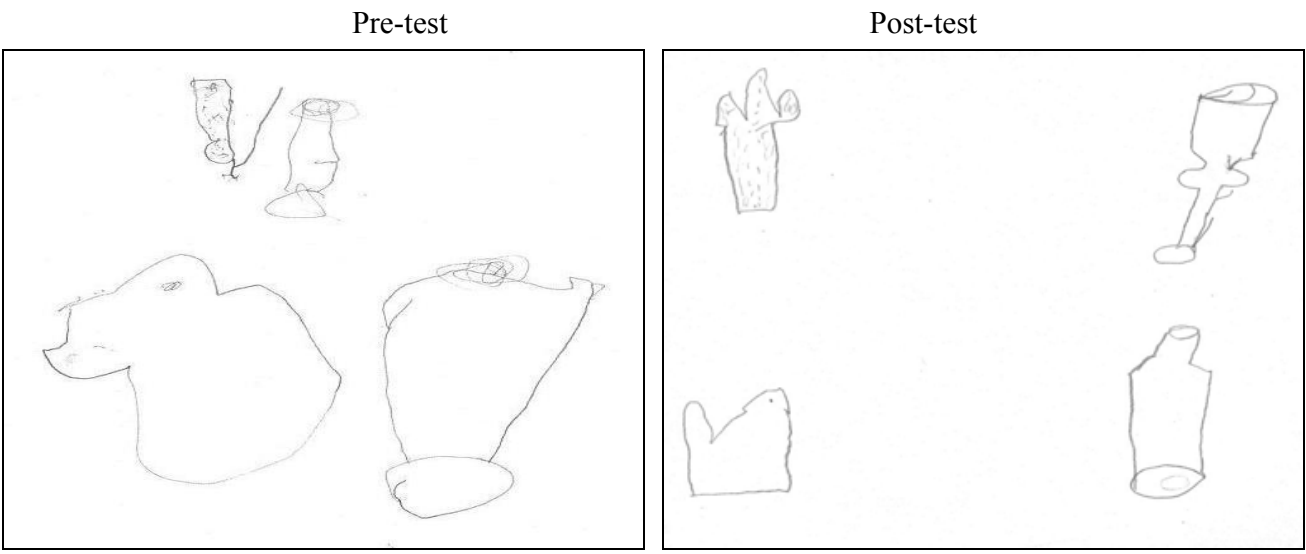

Figure 10. Example 10: Copy of four objects, before and after application of the program ("Draw these objects").
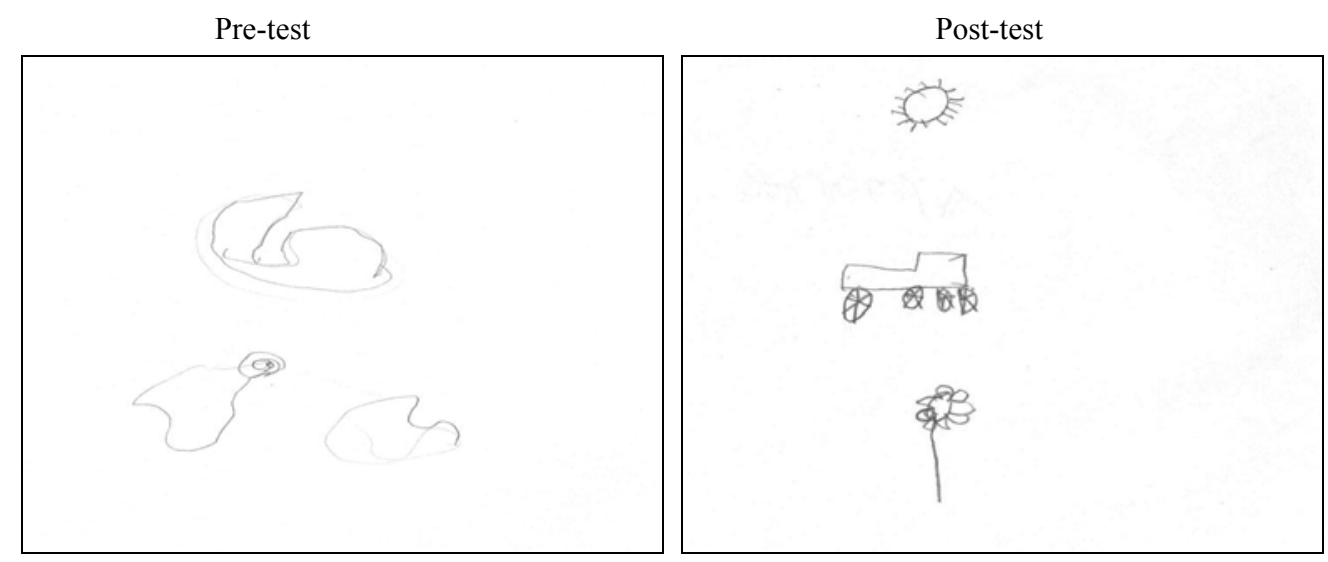

Figure 11. Example 11: Free drawing of three objects, before and after application of the program.

\section{Discussion}

It is considered that pre-school children are able to express themselves by drawing without any preparation or special orientation. Generally, the level of acquisition of graphic abilities is very low before entering the school. As one of the consequence, strong difficulties in writing related to visual and spatial functions appear in primary school. Common methods related to usage of drawing only provide few lessons or sessions without 
any specific orientation and do not consider psychological structure of graphic activity (Fortuna, 1998; Medina Ramirez, 2003). In such sessions, children are only asked what would they like to draw or represent in relation to a game or to a fairy tale, but they are never explained or guided in how to do it exactly and how to do it properly. Same methods are applied for introduction of reading or creation of perception of global images of words (Ferreiro \& Teberosky, 2005). Perceptive difficulties and errors in graphic representation are always been described as "normal stages of development".

In other studies, the authors mention the importance of drawing activity for assessment of diverse aspects of children's development or emotional aspects of personality. Again, psychologist only asked children to draw something and afterwards they proceed to analyze children's mistakes and difficulties without any possibility to improve their executions (Goodenough \& Harris, 1963; Kellog, 1987; Merino, Honores, García, \& Salazar, 2008).

The importance of gradual introduction of drawing in pre-school age is obvious. Different psychologists starting with L. S. Vigotsky himself have explained significance of drawing and other kind of artistic activities for young children (Vigotsky, 2001). Davidov (2008) stressed the importance of development of fine perception by enriching all kinds of experience with visual images. According to this author, imagination is one of central requisites of preparation for school. In children neuropsychology, the method of drawing is constantly used as one of the most powerful strategies for overcoming of spatial global and analytic deficits (Solovieva \& Quintanar, 2008; Akhutina \& Pilayeva, 2003, 2012a; Akhutina \& Zolotariova, 2007; Mata, 2011).

According to historical and cultural conception of children's development and activity theory, it is necessary to introduce and to guide the children in their activities. In other words, it is necessary to introduce new activity, which means to use the zone of proximate development. We claim that it is necessary to reconsider the term of the zone of proximate development. It is not possible to use this term as something general and abstract, but to create, for each case of concrete activity specific conditions in which it is possible to work in the "zone". The followers of Vigotsky's cultural conception of psychological development have created specific kind of orientation in order to guarantee formation of actions, which do not exist in the children. Recently, the importance of working with perception by drawing dividing between children and adult was stressed in research in Venezuela (Escobar \& Romero, 2003). In this case, the orientation provided by an adult consisted only in verbal characterization of an object or classes of objects, which were elected for drawing. Another example of such kind of proposal for development of drawing is a serial manuals created by Russian psychologists (Salmina \& Glebova, 2005a; 2005b). In these albums, the authors pre-sent multiple exercises useful for identification of shapes and orientation of lines. All these activities are presented at perceptive level. In the research, the authors propose to start on material level of concrete objects so that children could feel and appreciate all features of the objects. After that the authors pass to perceptive level when they work with lines and images. The materialized orientation is presented all the time in order to facilitate identification of shapes in real and perceptive objects. The introduction of graphic activity is based on initial usage of gestures, actions, and external shapes of objects.

Now, it can be said that it is not enough "to help" and "to assist", it is necessary to provide specific psychological orientation or orientation base of action, which permits to transform the zone of proximate development into the zone of actual development of children. Only in this case, drawing activity can be formed which can help to prevent learning disabilities. Our method permits not only organizing assessment, but also developing drawing activity in pre-school children. 


\section{Conclusions}

It can be concluded that drawing is extremely useful activity for preparation for school learning, especially for writing process.

Such activity has positive effect on spatial functions and images of objects in visual modality.

Children with unfavorable social conditions of life and learning can achieve positive results in acquisition of graphic activity as consequence of correspondent pedagogical methods.

Drawing may be used in pre-school institutions in order to guarantee required level of psychological readiness for school learning.

According to results of assessment, introduction of drawing may serve as useful training of spatial analysis and synthesis from pre-school age.

Specific orientation as amplification of the "zone of proximate development" should be used during introduction of drawing activity.

\section{References}

Akhutina, T. V. (2002). Diagnosis and correction of writting. Revista Española de Neuropsicología, 4(2-3), $236-261$.

Akhutina, T. V., \& Inshakova, O. B. (2008). Neuropsychological diagnosis and assessment of writting and reading in pupils pf primary school. Moscow: Creative Centre V. Sekachev.

Akhutina, T. V., \& Pilayeva, N. M. (2003). Diagnosis and development of visuo-verbal functions. Moscow: Academia.

Akhutina, T. V., \& Pilayeva, N. M. (2012a). Overcoming learning disabilities: A Vigotskian-Lurian neuropsychological approach. Cambridge: Cambridge University Press.

Akhutina, T. V., \& Pilayeva, N. M. (2012b). Escuela de la atención: Material didáctico para niños con problemas de la atención. México: Universidad Autónoma de Puebla.

Akhutina, T. V., \& Zolotariova, E. V. (2007). On the problem of visuo-spatial dysgraphy: Neuropsychological analysis and methods of correction. In L. Quintanar, \& Yu. Solovieva (Eds.), Methods of intervention in child neuropsychology (pp. 39-46). Mexico: Puebla Autonomous University.

Akhutina, T. V., Kamardina, I. O., \& Pilayeva, N. M. (2012). Neuropsicólogo en la escuela. Moscú: Centro V. Sekachev.

Cisneros, N. (2010). Características neuropsicológicas del proceso de la escritura en niños con problemas en el aprendizaje de 7 a 12 años. México: Universidad Autónoma de Puebla.

Elkonin, D. B. (1995). Desarrollo psicológico en las edades infantiles. Moscú: Academia de Ciencias Pedagógicas y Sociales.

Elkonin, D. B. (2009). Hacía el problema de la periodización del desarrollo en la edad infantil. In L. Quintanar, \& Yu. Solovieva (Eds.), Las funciones psicológicas en le desarrollo del niño. México: Trillas.

Escobar, M., \& Romero, K. (2003). Desarrollo de la representación del cuerpo humano y la familia en el niño preescolar a a través de las artes: Reflexiones teóricas. Educere, 6 (21), 33-39. Venezuela: Universidad de las Andes.

Ferreiro, E., \& Teberosky, A. (2005). Los sistemas de escritura en el desarrollo del niño. México: Siglo XXI.

Fortuna, J. (1998). Cuadernos de pedagogía: El dibujo como expresión de pensamiento. In M. Moreno (Ed.), Ciencia, aprendizaje y comunicación (pp. 155-171). Barcelona: Laia.

Glozman, J. M. (2009). Neuropsicología de la edad infantil. Moscú: Academia.

Goodenough, F., \& Harris, D. B. (1963). The Goodenough—Harris drawing test. New York: Harcourt, Brace, and World.

Kellogg, R. (1987). Analysis of plastic expression of a preschool child. Bogotá: Cincel Kapelusz.

Leontiev, A. N. (1983). Sellected psychological works. Moscow: Moscow State University.

Mata, A. (2011). Application of the program for guided formation of drawing in children with learning disabilities. (Masteral dissertation, Mexico: Autonomous University of Mexico)

Medina Ramirez, A. F. (2003). Playing with lines: Analysis of playing dinamic in graphic and literature expression in children. Mexico: Trillas.

Merino, C., Honores, L., García, W., \& Salazar, G. (2008). Prueba de habilidad intelectual para el dibujo de una persona e niños, adolescentes y adultos (DAP: IQ). Repsi, 17, 9-13.

Obukhova, L. F. (2006). Developmental psychology. Moscow: Superior education. 
Paz, G. (2012). Neuropsychological and electrophysiological correlations of analysis of ADDH in primary school. (Masteral dissertation, Mexico: Puebla Autonomous University)

Pilayeva, N. M., \& Akhutina, T. V. (2009). School of multiplication. Moscú: Terevinf.

Quintanar, L., \& Solovieva, Yu. (2007). Neuropsicología y aprendizaje escolar. Ciencia y Desarrollo, 33(212), 61-65.

Quintanar, L., Solovieva, Yu., \& Bonilla, R. (2006). Analysis of visuospatial activity in prescholar children with attention deficit disorder. Human Physiology, 32(1), 43-46.

Quintanar, L., Solovieva, Yu., Lázaro, E., Bonilla, R., Mejía, L., \& Eslava, J. (2009). Difficulties in the process of reading and writting. México: Trillas.

Rocha, J., Quintanar, L., \& Solovieva, Yu. (2005). El desarrollo de las imágenes internas en niños con alteraciones del lenguaje. Cuadernos Hispanoamericanos de Psicología, 5(1), 15-26.

Rojas, J. H. (2011). Clinical characterization of school children with learning disabilities. (Masteral dissertation, Puebla Autonomous University)

Salmina, N. G. (2009). Learning to think (Parts I-II). Moscow: Ventana-Graf.

Salmina, N. G. (2010). Indicators of preparation for school learning. In Yu. Solovieva, \& L. Quintanar (2010), Antology of psychological development of preschool child (pp. 67-74). Trillas: México.

Salmina, N. G., \& Filimonova, O. G. (2001). Diagnosis and correction of voluntary activity in preschool and school children. Mexico: Tlaxcala Autonomous University.

Salmina, N. G., \& Filimonova, O. G. (2010). Diagnosis and correction of previous mathematic habilities in pre-school children and pupils of primary school. Mexico: Institute of advanced studies.

Salmina, N. G., \& Glebova, A. O. (2005a). Learning to draw: Analysis of shapes and creation of images. Moscow: Ventana-Graf.

Salmina, N. G., \& Glebova, A. O. (2005b). Learning to draw: Lines and curves. Moscow: Ventana-Graf.

Solovieva, Yu., \& Quintanar, L. (2008). Child neuropsychological education. México: Trillas.

Solovieva, Yu., \& Quintanar, L. (2009). Brief neuropsychological assessment for children. Mexico: Puebla Autonomous University.

Solovieva, Yu., \& Quintanar, L. (in press). Method for drawing formation in pre-school children. Mexico: Trillas.

Solovieva, Yu., Quintanar, L., \& Lázaro, E. (2002). Evaluación neuropsicológica de escolares rurales y urbanos desde la aproximación de Luria. Revista Española de Neuropsicología, 4(2-3), 217-235.

Solovieva, Yu., Machinskaya, R., Quintanar, L., Bonilla., R., \& Pelayo, H. (2009). Neuropsychology and electrophysiology of $A D D H$ in pre-school age. Mexico: Puebla Autonomous University.

Talizina, N. F. (2009). Activity theory for teaching. Mexico: Puebla Autonomous University.

Vigotsky, L. S. (1995). Selected works (Vol. 3). Madrid: Visor.

Vigotsky, L. S. (1996). Selected works (Vol. 4). Madrid: Visor.

Vigotsky, L. S. (2001). Imagination and art in infancy. México: Ediciones Coyoacan. Psicología. 